\title{
PENGARUH SELF-HELP GROUPS TERHADAP PENURUNAN DEPRESI PADA MANTAN PEMAKAI NARKOBA DI LEMBAGA PEMASYARAKATAN PEREMPUAN
}

\author{
Ilma Widiya Sari ${ }^{1}$, Mateus Sakundarno Adi ${ }^{2}$, Megah Andriany ${ }^{3}$ \\ ${ }^{1}$ Program Studi Magister Keperawatan, Universitas Diponegoro Semarang \\ ${ }^{2}$ Departemen Epidemiologi, Universitas Diponegoro Semarang \\ ${ }^{3}$ Departemen Keperawatan, Universitas Diponegoro Semarang \\ E-mail: ilmawidi@gmail.com
}

\begin{abstract}
Depression among prisoners is also found in many female former drug users. Treatment to prevent the negative effects of depression should be immediately provided for the former drug users. Self-help groups as an alternative strategy to improve the support system to create an adaptive coping that can reduce depression level. The purpose of this study was to analyze the effect of self-help groups on depression level in former drug users. The research design used was pre-experiment with one group pre-test and post-test design. Sampling technique using purposive sampling, where only the former drug users who used as sample 19 respondents. Depression level were assessed using Beck Depression Inventory (BDI) II. The result of paired t-test showed that the mean of depression rate has decreased statistically significant, where $p$ value is less than alpha $(0,022<0,05)$. It can be concluded that there is effect of self-help groups on depression level in former drug users.
\end{abstract}

Keywords: self-help groups, depression, former substance users

\begin{abstract}
Abstrak: Depresi pada warga binaan di penjara juga banyak ditemukan pada warga binaan wanita mantan pemakai narkoba. Perawatan untuk mengantisipasi efek buruk depresi harus segera diberikan bagi warga binaan mantan pemakai narkoba. Self-help groups dipandang sebagai strategi alternatif untuk meningkatkan sistem dukungan sehingga tercipta koping yang adaptif dan dapat menurunkan depresi. Tujuan penelitian ini untuk menganalisis pengaruh self-help groups terhadap penurunan depresi pada mantan pemakai narkoba. Desain penelitian yang digunakan adalah preexperiment dengan one group pre-test and post-test design. Teknik pengambilan sampling menggunakan purposive sampling, dimana hanya warga binaan mantan pemakai narkoba yang dijadikan sampel sejumlah 19 responden. Tingkat depresi dinilai menggunakan Beck Depression Inventory (BDI) II. Hasil analisis paired t-test menunjukkan bahwa rata-rata tingkat depresi mengalami penurunan yang signifikan secara statistik, dimana nilai $p$ lebih kecil daripada nilai alpha $(0,022<0,05)$. Dengan demikian dapat disimpulkan bahwa terdapat pengaruh self-help groups terhadap penurunan tingkat depresi pada mantan pemakai narkoba.
\end{abstract}

Kata kunci: self-help groups, depresi, mantan pemakai narkoba

\section{PENDAHULUAN}

Depresi merupakan penyebab utama gangguan mental dan kecacatan di seluruh dunia. World Health
Organization (WHO) menyebutkan bahwa jumlah populasi global yang mengalami depresi sekitar 322 juta penduduk, meningkat sebesar $18,4 \%$ 
antara tahun 2005 hingga 2015. Prevalensi depresi tertinggi ditemukan di wilayah Asia Tenggara, yaitu sekitar 85,67 juta penduduk (27\% dari total penduduk yang mengalami depresi), dimana kejadian depresi pada penduduk perempuan lebih tinggi dibandingkan pada penduduk laki-laki (World Health Organization, 2017).

Depresi dalam suatu komunitas dapat disebabkan putusnya pemakaian narkoba atau pengobatan pada pecandu narkoba. Gangguan depresi pada warga binaan di penjara juga banyak ditemukan pada warga binaan wanita mantan pemakai narkoba (Johnson \& Zlotnick, 2012). Sebuah studi berkelanjutan mulai tahun 2003 sampai 2009 di Florida menyatakan bahwa depresi merupakan salah satu masalah utama dalam penjara, sebanyak $25 \%$ warga binaan diindikasikan menderita depresi berat, sedangkan 30\% lainnya diindikasikan menderita depresi ringan sampai sedang (Gussak, 2009).

Depresi adalah gangguan mood, konsep diri yang negatif yang berlanjut pada perasaan rendah diri, gangguan terhadap fungsi fisiologis dan kondisi emosional berkepanjangan yang mewarnai seluruh proses mental (berpikir, berperasaan dan berperilaku) (Beck, 2009). Depresi merupakan gangguan mental yang sering terjadi di tengah masyarakat. Berawal dari stress yang tidak diatasi, maka seseorang dapat jatuh ke fase depresi. Seseorang yang mengalami depresi umumnya mengalami gangguan yang meliputi keadaan emosi, motivasi, fungsional, dan gerakan tingkah laku serta kognisi (Shives, 2012).

Strategi koping pada warga binaan memberikan kontribusi pada kecenderungan depresi saat menghadapi kejadian yang penuh tekanan (Cooper, Livingston, Cooper,
\& Livingston, 2007). Depresi dapat timbul karena kurangnya dukungan sosial terhadap seseorang yang memiliki gejala depresi. Berkurangnya dukungan sosial dapat melemahkan kemampuan untuk mengatasi masalah dan membuat semakin rentan terhadap depresi (Davidson, Neale, \& Kring, 2002).

Depresi merupakan gangguan mental yang berkontribusi terhadap kejadian bunuh diri pada warga binaan (Baier, Fritsch, Ignatyev, Priebe, \& Mundt, 2016). Depresi pada warga binaan yang tidak tertangani dapat meningkatkan masalah kesehatan masyarakat (Uche \& Princewill, 2015). Perawatan untuk mengantisipasi efek buruk depresi harus segera diberikan bagi warga binaan mantan pemakai narkoba.

Perawatan depresi meliputi perawatan non-obat (psikoterapi), obat antidepresan (farmakoterapi) atau kombinasi keduanya. Khusus untuk individu dengan depresi ringan atau sedang, psikoterapi menjadi pilihan utama dalam perawatan depresi (Barth et al., 2012). Efektivitas psikoterapi dan farmakoterapi sebanding dalam mengurangi gejala depresi. Selain itu, kedua terapi tersebut juga memiliki efektivitas yang sama untuk mengatasi depresi ringan dan sedang (Leucht, Helfer, Gartlehner, \& Davis, 2015).

Penguatan dukungan sosial diperlukan dalam perawatan warga binaan selama selama di penjara (Sacks \& Kressel, 2007). Self-help groups dipandang sebagai strategi alternatif untuk meningkatkan sistem dukungan dalam kesehatan masyarakat (Aglen, Hedlund, \& Landstad, 2015; Brown, Tang, \& Hollman, 2014). Intervensi ini dapat menjadi sarana membangun dan memelihara hubungan sosial pada orang-orang dengan masalah kesehatan mental 
sehingga terbentuk koping yang adaptif (Aglen et al., 2015).

Self-help groups merupakan kelompok dimana anggotanya mengatur diri untuk menyelesaikan masalah. Para anggota kelompok berbagi pengalaman yang sama, bekerja sama mencapai tujuan bersama serta menggunakan kekuatan kelompok untuk mengendalikan perilaku. Proses yang terlibat dalam self-help groups adalah afiliasi sosial, belajar mengendalikan diri, menurunkan stress serta tindakan untuk mengubah lingkungan sosial (Stuart \& Laraia, 2009).

Tujuan self-help groups adalah memberikan dukungan emosional setiap anggota kelompok, belajar koping yang adaptif, serta menemukan strategi untuk mengatasi suatu kondisi dan memberikan bantuan kepada setiap anggota kelompok (Coote \& Macleod, 2012; Mccann, Songprakun, \& Stephenson, 2016). Pembentukan self-help groups mencegah timbulnya perubahan perasaan atau mood dan depresi serta tercapainya perasaan aman dan sejahtera (Salomon, 2004). Selain itu, self-help groups juga memberikan kepuasan karena dapat berbagi dan membantu satu dengan yang lainnya (Coote \& Macleod, 2012).

Self-help groups telah terbukti efektif untuk mengurangi gejala depresi pada pasien dengan masalah fisik (Matcham et al., 2014). Intervensi tersebut berfokus pada materi terkait perawatan penyakit (Aglen et al., 2015; Komatsu et al., 2012; Matcham et al., 2014; Mccann et al., 2016). Depresi yang dialami warga binaan lebih berfokus berfokus pada permasalahan yang timbul akibat putus dari pemakaian narkoba (Johnson \& Zlotnick, 2012). Perbedaan fokus masalah antara kedua populasi tersebut memungkinkan adanya perbedaan prosedur dalam selfhelp groups. Dengan demikian, penelitian ini dilakukan bertujuan untuk menganalisis pengaruh self-help groups terhadap penurunan depresi pada mantan pemakai narkoba di lembaga pemasyarakatan perempuan.

\section{METODE PENELITIAN}

Desain penelitian yang digunakan adalah pre-experiment dengan one group pre-test and posttest. Pre-test dilakukan sebelum pemberian self-help groups dan setelah itu dilakukan pengukuran kembali (post-test). Populasi dalam penelitian ini adalah warga binaan perempuan yang tinggal di salah satu lembaga pemasyarakatan perempuan. Teknik pengambilan sampling menggunakan purposive sampling, dimana hanya warga binaan mantan pemakai narkoba yang dijadikan sampel sejumlah 19 responden.

Variabel bebas pada penelitian ini adalah self-help groups dan tingkat depresi sebagai variabel terikat. Kuesioner yang digunakan untuk mengukur tingkat depresi pada warga binaan perempuan adalah Beck Depression Inventory (BDI) II. BDI II dikembangkan Aaron Temkim Beck berjumlah 21 pernyataan yang terdiri atas tiga domain, yaitu gejala kognitif, afektif dan somatik. Kuesioner BDI II yang berbahasa Indonesia diadopsi dari penelitian yang dilakukan Jodi di salah satu Lapas Perempuan (Jodi, 2016).

Pelaksanaan intervensi dalam penelitian ini meliputi pre-test, pemberian self-help groups dan posttest. Pre test merupakan pengukuran tingkat depresi yang dilakukan sehari sebelum pemberian self-help groups. Intervensi self-help groups dilakukan dengan tahapan pembentukan 
kelompok dan implementasi. Waktu yang dialokasikan pada setiap pertemuan yaitu 60-90 menit. Implementasi self-help groups pada tiap pertemuan terdiri dari empat langkah, yaitu memahami masalah, cara untuk menyelesaikan masalah, memilih cara pemecahan masalah dan melakukan tindakan untuk menyelesaikan masalah.

Data yang sudah terkumpul kemudian dilakukan pengolahan. Analisis univariat digunakan untuk mendeskripsikan karakteristik responden. Analisis bivariat untuk membuktikan hipotesis yang telah dirumuskan. Sebelum dilakukan analisis bivariat, dilakukan uji normalitas data pada variabel tingkat derpesi untuk menentukan jenis uji statistik yang digunakan. Uji normalitas dilakukan dengan menggunakan uji Shapiro Wilk dimana jumlah sampel penelitian kurang dari 50. Hasil analisis menunjukkan bahwa data berdistribusi normal (nilai $p>$ 0,05) sehingga analisis bivariat menggunakan uji parametrik yaitu paired t-test.

\section{HASIL DAN PEMBAHASAN \\ Hasil}

Karakteristik responden dalam penelitian ini disajikan dalam tabel berikut:

Tabel 1. Distribusi Frekuensi Karakteristik Responden

\begin{tabular}{lcc}
\multicolumn{1}{c}{ Karakteristik } & Jumlah (n) & Persentase (\%) \\
\hline Umur & & \\
17-25 tahun & 4 & 21 \\
26-35 tahun & 9 & 47,4 \\
36-45 tahun & 3 & 15,8 \\
46-55 tahun & 2 & 10,5 \\
56-65 tahun & 1 & 5,3 \\
\hline Pendidikan & & \\
SD & 1 & 5,3 \\
SMP & 9 & 47,4 \\
SMA/SMK & 7 & 36,8 \\
Diploma & 2 & 10,5 \\
\hline
\end{tabular}

\begin{tabular}{llc}
\hline Status pernikahan & & \\
Belum menikah & 4 & 21 \\
Menikah & 8 & 42,1 \\
Janda & 5 & 26,3 \\
Single parent & 2 & 10,5 \\
\hline
\end{tabular}

Hasil penelitian menunjukkan bahwa umur responden yang terbanyak adalah 26-35 tahun. Warga binaan perempuan yang paling banyak mengalami depresi adalah warga binaan dalam rentang usia dewasa awal (19-40 tahun) (Unver, Yuce, Bayram, \& Bilgel, 2013). Situasi yang baru dihadapi sesorang dengan memasuki tahapan usia dewasa awal adalah situasi yang terkait dengan tugas perkembangan seperti menikah, membangun keluarga, melakukan suatu pekerjaan, dan membuat hubungan dengan suatu kelompok sosial. Dalam menjalankan tugas perkembangan tersebut, seringkali muncul konflik atau masalah yang berkaitan dengan tanggung jawab terhadap diri sendiri dan orang lain. Ketidakmampuan seseorang dalam menyesuaikan diri dan menyelesaikan persoalan hidup yang dialaminya dapat menimbulkan gejala depresi (Pinese, Furegato, \& Santos, 2010).

Responden pada penelitian ini sebagian besar berpendidikan SMP dan SMA/SMK. Tingkat pendidikan tinggi mempunyai kesempatan yang lebih untuk dapat mengembangkan kemampuan intelektualitas, kreatifitas, dan aktualisasi ilmu pengetahuannya dalam menghadapi tantangan hidup, namun tidak menjamin menampilkan perilaku yang adaptif (Baier et al., 2016).

Tabel 1 juga menyebutkan sebagian besar responden berstatus menikah. Warga binaan perempuan yang telah menikah lebih banyak ditemukan mengalami depresi dibandingkan yang belum menikah. Pernikahan membawa manfaat yang 
baik bagi kesehatan mental laki-laki dan perempuan. Namun, bagi pasangan suami istri yang gagal membina hubungan pernikahan atau ditinggalkan pasangan justru akan memicu terjadinya depresi (Osasona \& Koleoso, 2015).

Perbedaan tingkat depresi saat pre-test dan post-test pada mantan pemakian narkoba dianalisis menggunakan paired t-test. Hasil analisis dapat dilihat pada tabel berikut:

Tabel 2. Analisis Perbedaan Tingkat Depresi Responden saat Pre-Test dan Post-Test

\begin{tabular}{ccccc}
\hline $\begin{array}{r}\text { Tingkat } \\
\text { Depresi }\end{array}$ & Mean & SD & t & p-value \\
\cline { 1 - 3 } Pre-test & 14,53 & 5,6 & 2,512 & 0,022 \\
\cline { 1 - 3 } Post-test & 11,37 & 3,2 & & \\
\hline
\end{tabular}

Hasil analisis pada tabel 2 menunjukkan bahwa nilai rata-rata tingkat depresi saat pre-test dan posttest mengalami penurunan. Perbedaan nilai rata-rata tingkat depresi saat pretest dan post-test bermakna secara statistik, dimana nilai $p$ lebih kecil daripada nilai alpha $(0,022<0,05)$. Dengan demikian dapat disimpulkan bahwa terdapat pengaruh self-help groups terhadap penurunan tingkat depresi pada mantan pemakai narkoba.

Self-help groups telah terbukti efektif untuk mengatasi masalah gangguan mental. Self-help groups dipandang sebagai strategi alternatif untuk meningkatkan sistem dukungan dalam kesehatan masyarakat. Intervensi ini dapat menjadi sarana membangun dan memelihara hubungan sosial pada orang-orang dengan masalah kesehatan mental sehingga terbentuk koping yang adaptif (Aglen et al., 2015; Siller, Renner, \& Juen, 2016).

Dalam self-help groups, responden saling berbagi pengalaman terkait permasalahan yang dihadapi setelah putus pemakaian narkoba. Selfhelp groups dilakukan agar setiap anggota kelompok dapat berbagi pengalaman dan harapan terhadap pemecahan masalah serta menemukan solusi melalui kelompok. Informasi dari anggota kelompok dan solusi yang dapat dilakukan merupakan kekayaan bagi anggota kelompok dan sebagai bahan pertimbangan untuk membantu anggota kelompok yang bermasalah (Pistrang, Barker, \& Humphreys, 2008).

Setiap anggota dalam self-help groups akan memiliki pengalaman sehingga dapat menjadi role model bagi orang lain. Tingkah laku manusia dalam bentuk interaksi timbal balik yang terus menerus akan saling mempengaruhi dalam fenomena psikososial. Penelitian sebelumnya menunjukkan bahwa interaksi timbal balik dalam self-help groups dapat menurunkan tingkat depresi (Field, Diego, Delgado, \& Medina, 2013; Siller et al., 2016; Utami, 2008). Sejalan dengan hal tersebut, role model bagi responden yang membutuhkan solusi pemecahan masalah dilakukan melalui role play.

Pengalaman dan informasi yang didapat selama self-help groups dapat dijadikan sumber koping bagi warga binaan sehingga tercapai koping yang adaptif dan masalah depresi dapat teratasi. Hal tersebut sesuai dengan karakteristik self-help groups yang dikemukakan Aglen, yaitu selfhelp groups sebagai proses intrapsikologis, sebagai koping, pembelajaran individu, dan pemberdayaan (Aglen et al., 2015). Proses intrapsikologis merupakan proses adaptasi psikologis yang berhubungan dengan aspek pemahaman, penerimaan, dan pemaknaan kehidupan. Self-help groups sebagai koping 
menggambarkan kemampuan seseorang untuk mengendalikan kehidupan. Studi pemberdayaan mengaitkan seseorang dapat memotivasi dan memobilisasi sumber daya yang dimiliki untuk memecahkan masalah.

Penurunan tingkat depresi melalui self-help groups berkaitan dengan adanya penguatan dukungan sosial (Brown et al., 2014; Siller et al., 2016). Pada penelitian sebelumnya, dukungan sosial dapat memberikan penguatan dan kendali diri pada seseorang. Penguatan dukungan sosial dapat menimbulkan perasaan lega dan nyaman (Brown et al., 2014). Dengan demikian, adanya penguatan dukungan sosial dapat menurunkan tingkat depresi responden

\section{SIMPULAN DAN SARAN Simpulan}

Berdasarkan hasil penelitian disimpulkan bahwa terdapat pengaruh self-help groups terhadap penurunan tingkat depresi pada mantan pemakai narkoba. Self-help groups dapat dijadikan strategi alternatif dalam membangun dukungan sosial, dimana setiap anggota kelompok dapat berbagi pengalaman dan saling membantu untuk memecahkan masalah. Melalui self-help groups akan tercipta koping yang adaptif sehingga dapat menurunkan tingkat depresi.

\section{Saran}

Mantan pemakai narkoba yang mengalami depresi jika tidak segera ditangani akan menyebabkan penderitanya mengalami berbagai gejala negatif. Oleh karena itu, sebaiknya dikembangkan program perawatan depresi bagi mantan pemakai narkoba di lembaga pemasyarakatan salah satunya dengan intervensi self-help groups yang terbukti dapat menurunkan tingkat depresi.

Penelitian ini menggunakan desain pre-experiment dengan jumlah sampel relatif kecil sehingga diharapkan penelitian ini dapat dikembangkan menggunakan desain penelitian yang lebih baik dan jumlah sampel yang lebih besar. Selain itu, diharapkan intervensi ini dapat diteliti untuk mengatasi permasalahan kesehatan lainnya.

\section{DAFTAR PUSTAKA}

Aglen, B., Hedlund, M., \& Landstad, B. J. (2015). Self-help and selfhelp groups for people with longlasting health problems or mental health difficulties in a Nordic context: A review, (September 2011),

813-822. https://doi.org/10.1177/14034948 11425603

Baier, A., Fritsch, R., Ignatyev, Y., Priebe, S., \& Mundt, A. P. (2016). The course of major depression during imprisonment - A one year cohort study. Journal of Affective Disorders, 189, 207-213. https://doi.org/10.1016/j.jad.2015 .09 .003

Barth, J., Munder, T., Gerger, H., Nüesch, E., Trelle, S., Znoj, H., ... Cuijpers, P. (2012). Comparative Ef fi cacy of Seven Psychotherapeutic Interventions for Patients with Depression: A Network, 229-243. https://doi.org/10.1176/appi.focus .140201

Beck, A. T. (2009). Depression: causes and treatment (Second edi). Philadelphia: University of Pennsylvania Press.

Brown, L. D., Tang, X., \& Hollman, R. L. (2014). The Structure of Social Exchange in Self-help 
Support Groups : Development of a Measure, 83-95. https://doi.org/10.1007/s10464013-9621-3

Cooper, C., Livingston, M., Cooper, C., \& Livingston, M. (2007). Work \& Stress : An International Journal of Work, Health \& Depression and coping mechanisms in prisoners Pilot sttldy Depression and coping mechanisms in prisoners, (December 2014), 37-41. https://doi.org/10.1080/02678379 108257011

Coote, H. M. J., \& Macleod, A. K. (2012). A Self-help , Positive Goal-focused Intervention to Increase Well-being in People with Depression, 315(May), 305315.

https://doi.org/10.1002/cpp.1797

Davidson, G. C., Neale, J. M., \& Kring, A. M. (2002). Psikologi Abnormal (Edisi Kese). Jakarta: Rajawali Press.

Field, T., Diego, M., Delgado, J., \& Medina, L. (2013). Early Human Development Peer support and interpersonal psychotherapy groups experienced decreased prenatal depression, anxiety and cortisol. Early Human Development, 89(9), 621-624. https://doi.org/10.1016/j.earlhum dev.2013.04.006

Gussak, D. (2009). The Arts in Psychotherapy Comparing the effectiveness of art therapy on depression and locus of control of male and female inmates. The Arts in Psychotherapy, 36, 202207.

Jodi, T. (2016). Gambaran Depresi pada Warga Binaan Perempuan Di LP Bulu Semarang. Universitas Diponegoro.

Johnson, J. E., \& Zlotnick, C. (2012).
Pilot study of treatment for major depression among women prisoners with substance use disorder. Journal of Psychiatric Research, 46(9), 1174-1183. https://doi.org/10.1016/j.jpsychire s.2012.05.007

Komatsu, H., Hayashi, N., Suzuki, K., Yagasaki, K., Iioka, Y., Neumann, J., ... Ueno, N. T. (2012). Guided Self-Help for Prevention of Depression and Anxiety in Women with Breast Cancer, 2012. https://doi.org/10.5402/2012/716 367

Leucht, S., Helfer, B., Gartlehner, G., \& Davis, J. M. (2015). How effective are common medications : a perspective based on meta-analyses of major drugs. BMC Medicine, 1-5. https://doi.org/10.1186/s12916015-0494-1

Matcham, F., Rayner, L., Hutton, J., Monk, A., Steel, C., \& Hotopf, M. (2014). Clinical Psychology Review Self-help interventions for symptoms of depression, anxiety and psychological distress in patients with physical illnesses: A systematic review and meta-analysis. Clinical Psychology Review, 34(2), 141157.

https://doi.org/10.1016/j.cpr.2014 .01 .005

Mccann, T. V, Songprakun, W., \& Stephenson, J. (2016). Ef fi cacy of a self-help manual in increasing resilience in carers of adults with depression in Thailand, $\quad 62-70$. https://doi.org/10.1111/inm.1217 8

Osasona, S. O., \& Koleoso, O. N. (2015). Prevalence and correlates of depression and anxiety 
disorder in a sample of inmates in a Nigerian prison. https://doi.org/10.1177/00912174 15605038

Pinese, C. S. V, Furegato, A. R. F., \& Santos, J. L. F. (2010). Demographic and clinical predictors of depressive symptoms among incarcerated women, 1-7.

Pistrang, N., Barker, Æ. C., \& Humphreys, Æ. K. (2008). Mutual Help Groups for Mental Health Problems: A Review of Effectiveness Studies, 110-121. https://doi.org/10.1007/s10464008-9181-0

Sacks, A. N. N. Y., \& Kressel, D. (2007). In treatment using the client assessment inventory, 34(9), 1131-1142. https://doi.org/10.1177/00938548 07304346

Salomon, P. (2004). Peer support underlying processes, benefits and critical ingredients. Psychiatric Rehabillitation Journal, 27(4).

Shives, L. (2012). Basic Concepts of Psychiatric-Mental Health Nursing (Eighth edi). Philadelphia: Wolters KluwerHealth/Lippincott Williams \& Wilkins.

Siller, H., Renner, W., \& Juen, B. (2016). Turkish Migrant Women with Recurrent Depression :
Results from Community-based Self- help Groups, 4289(March). https://doi.org/10.1080/08964289 .2015 .1111858

Stuart, G. W., \& Laraia, M. T. (2009). Principles and practice of psychiatric nursing. St. Louis Missouri: Mosby Inc.

Uche, N., \& Princewill, S. (2015). Clinical Factors as Predictors of Depression in a Nigerian Prison Population Clinical Factors as Predictors of Depression in a Nigerian Prison Population, (January 2015). https://doi.org/10.4172/23785756.1000345

Unver, Y., Yuce, M., Bayram, N., \& Bilgel, N. (2013). Psychiatry / behavioral science prevalence of depression, anxiety, stress, and anger in Turkish Prisoners, 58(5), 1210-1218.

https://doi.org/10.1111/15564029.12142

Utami, T. (2008). Pengaruh self help group terhadap kemampuan di Kelurahan Sindang Barang Bogor. Universitas Indonesia.

World Health Organization. (2017). Depression and Other Common Mental Disorders Global Health Estimates. 